\title{
The Perception Versus The Reality Of Retirement: Are You Ready To Retire?
}

Dan Yates, Ph.D., University of Findlay, USA

Chris Ward, Ed.D., University of Findlay, USA

\begin{abstract}
This study explored the perceptions and the reality of retirement of two groups in northwest Ohio: those planning to retire within five years and those who are currently retired. A survey was constructed to capture the thoughts on retirement, living arrangements in retirement, travel plans, work and volunteer plans, concerns about retirement, philanthropy, working with advisors, and retirement income and debt. Obtaining information pertaining to these areas will assist financial advisors/planners in better serving their clients' financial future as well as provide 'retirement readiness" information for those considering retirement in the near future.
\end{abstract}

Keywords: Financial Advisors; Retirement; Retirement Lifestyles

\section{INTRODUCTION}

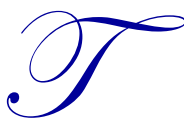

he firm of Strategic Investment Advisors (SIA) of Findlay, Ohio surveyed clients to gather information about their retirement. More specifically, the survey was designed to explore the perceptions and the reality of retirement of two retirement groups in northwest Ohio: those planning to retire within five years and those who are currently retired. The survey was constructed to capture their thoughts on retirement, living arrangements in retirement, travel plans, work and volunteer plans, concerns about retirement, philanthropy, working with advisors, and retirement income and debt.

Our goal for this pilot study was to obtain information pertaining to these areas that will assist professionals in better serving their clients' financial future as well as provide a "retirement readiness" resource for those considering retirement in the near future. For comparative purposes, survey information from the 2011 Retirement Confidence Survey (RCS) was included in the results section. The RCS is conducted annually by The Employee Benefit Research Institute (EBRI) which is a Washington, DC based organization (see reference notes).

\section{LITERATURE REVIEW}

Those considering retirement in the near future are facing issues that are different from their predecessors. Issues such as the mortgage foreclosures, declining real estate values (i.e., the housing bubble in 2007), lack of investment portfolio growth, high unemployment rates, corporate downsizing, etc. have raised questions for preretirees. When should I retire? Would it be better to delay retirement and continue to work? Will I have enough money to live on?

Rosnick and Baker (2010) conducted a study that used data from the Federal Reserve Board's 2007 Survey of Consumer Finances (SCF) before the housing crash with projections of household wealth following the crash. Their study updated two previous papers that constructed projections based on the 2004 SCF (Baker \& Rosnick, 2008; Rosnick \& Baker, 2009). Rosnick \& Baker (2010) noted their study had important policy implications for pension policies based on if most baby boomers were unable to accumulate enough savings and wealth to support a decent retirement life, then there would a need for improvements in the retirement system. The results of their study found that the projections for 2009 would suggest that "baby boom cohorts will be very poorly prepared for retirement" (p.126). The study noted that recent economic projections show the economy below capacity until 2014, along with weaknesses in the labor market, it would be more difficult to find well-paying jobs or to find work at all. 
Many baby boomers will find it difficult to build wealth over the next few years and this could have a substantial impact on their retirement security. This means that the "new" retirees would likely be more dependent on Social Security.

Edward Wolff (2002) found most families were poorly prepared for retirement even before the technology bubble crash based on a SCF analysis. In an update to this study, Weller \& Wolff (2005) projected that $20 \%$ and $60 \%$ of homeowners and renters respectively, would not have enough wealth (including Social Security benefits) to provide income of twice the poverty line. Munnell, Golub-Sass, Soto, and Webb's (2008) study also found that baby boomers would not have sufficient wealth to sustain their standard of living throughout their retirement years.

In a Time magazine article, Gandel (2009) noted that even prior to the financial crises, baby boomers had not saved enough for their retirement. Gandel's example showed that in 1998, the average 50-year-old (working for at least ten years) had a balance of $\$ 85,000$ in a $401 \mathrm{~K}$ account according to the Employee Benefit Research Institute. Factoring in the market drop (2009) and a decade later, the $401 \mathrm{~K}$ balance has only grown to $\$ 93,000$. The boomers are ten years older, but their wealth growth remained virtually the same. Gandel cited that while boomers attempt to hang on to their jobs, younger generations will be crowded out of the job market. According to the Center for Labor Market Studies at Northeastern University, the employment rates have fallen for teens and 20-somethings this decade.

Krepcio's (2007) research found that a growing number of boomers who had thought their retirement resources would be sufficient will likely need the assistance of the government and nonprofits in their later years. Krepcio also noted that boomers will work longer than previous generations. America has the lowest overall savings rate of any major industrialized nation as demonstrated by the personal savings rate of less than zero. The bottom line is that older workers can't afford to quit their jobs.

An article in Kiplinger's Personal Finance (February, 2011) magazine cited several studies regarding baby boomers staying in the workforce longer. Eighty percent of U.S. workers responding to a Sun Life Survey will need at least three years of additional employment to rebuild their retirement funds. A poll by Towers Watson found that forty percent of U.S. workers plan to delay their retirement noting that two-thirds of them cited the access to their employer's healthcare coverage. A recent poll by Charles Schwab found that "age", not finances, drives most retirement decisions. Nearly fifty percent of the 50-60 year olds cited they have a target date for retirement as compared to $38 \%$ who base their target date on finances. The article also identified the benefits of working longer (i.e., delaying retirement) were increased retirement security, more time to accumulate savings, a bigger Social Security check, and less retirement savings needed with fewer years in retirement.

Ann Carrns' article in the U.S. News \& World Report (October, 2010) noted that many pre-retirees are rapidly rethinking their expectations about retirement. "The loss of confidence in financial markets is instilling a deep sense of insecurity" (p. 22), says Olivia Mitchell, director of the Boettner Center for Pensions and Retirement Research at the University of Pennsylvania's Wharton School. The number of retirement-age people still in the workforce was up 7 percent which provides extra time to save money and, with delaying their retirement date, will result in higher Social Security benefits each month.

Carrns encouraged boomers who expect their retirement savings to last more the two decades to find ways to increase their savings. The Employee Benefit Research Institute survey found that a majority of workers believe they will need at least $\$ 500,000$ in retirement savings, but less than $25 \%$ of those 55 and older had savings less than $\$ 250,000$. Carrns mentions that "making do with less is becoming downright trendy" for many entering retirement.

In a study of persons 50-59 years of age, Malonebeach and Langeland (2011) surveyed 225 persons regarding retirement status, current and anticipated civic engagement and work activities, household composition, and proximity of family members. The study found that $45 \%$ of the sample was retired, $33 \%$ intended to work to full retirement, and those not yet retired (52\%) expected to work in retirement.

Questions pertaining to the family, $64 \%$ of the sample had living parents and $56 \%$ of those had parents residing within 50 miles. Eighty-six percent had children and 50\% had children living within 50 miles. Eighty six 
percent valued spending time with their families and expected to prioritize their "family time" in retirement. The civic engagement questions resulted in $31 \%$ being currently involved in a volunteering activity while $96 \%$ expected to increase their civic activities in retirement. Seventy-three percent were concerned about managing their health and $64 \%$ reported they needed to improve their effort in living a healthy lifestyle. Fifty-four percent expressed concern about being able to afford the rising costs of health care. Ninety-four percent indicated they would enjoy learning new things while $23 \%$ expressed interests in educational activities. Sixty-eight percent said they would use a senior center and $29 \%$ indicated enjoying "group" activities. Boomers indicated that they intend to travel more.

Morris (2010) raises the issue of "estate planning" for baby boomers. One of the challenges is having enough money to support a healthy-active lifestyle which may require 75 to 80 percent of the last year's full-time employment income. Another challenge is the amount of wealth that can generate income. An AARP study in 2004 estimated the oldest of the baby boomers' wealth at age 67 at $\$ 850,000$ which includes home equity. The concern is that $\$ 850,000$ earning 5 percent will generate $\$ 42,500$ and most of that will be taxable, thus reducing spendable income to $\$ 30,000$. How many retirees can afford to live on $\$ 30,000$ and still have a very "active" lifestyle? This is optimistic knowing that the home equity amount will not generate any income unless one engages in a reverse mortgage.

Our study focused on the issues and circumstances that both pre-retirees and retirees are facing as both groups deal with decisions that impact their financial and personal lives as they consider retirement. The next section discusses the content areas of the retirement survey and how the survey was administered.

\section{METHODOLOGY}

A pilot survey was developed internally by the researchers. The pilot survey was tested by fifteen individuals consisting of current clients and college professors. This test group was instructed to examine the survey and its questions based on the following criteria: purpose, directness, utility, reliability, and validity. Changes and recommendations were submitted by the test group and the survey was revised by the researchers.

The survey focused on gathering information on the living arrangements in retirement, travel plans, work and volunteer plans, concerns about retirement, philanthropy, working with advisors, and retirement income and debt. The survey was targeted to three groups: those planning to retire within five years; those retired three years or less; and those retired more than three years.

Emails were sent to existing clients explaining the purpose of the survey. Instructions were provided on completing the online survey using Survey Monkey. Sixty persons responded to the survey based on the following categories: those planning to retire within five years (25 responded); those retired three years or less (11 responded); and those retired more than three years ( 24 responded). The data was collected and summarized using percentages. The number of those responding to the questions and those skipping the questions were recorded. The survey questions were closed-end and used a Likert-scale as well as both ordinal and categorical scaling.

The following additional information was gathered: the respondent's current age, age at retirement, monthly income need, debt amount, range of investable assets, would you like a summary of the research, and the best way to contact you.

\section{RESULTS}

The survey results were summarized into three categories:

- $\quad$ Psychology of retirement

- $\quad$ Lifestyle - work and leisure

- $\quad$ Financial aspects of retirement 


\section{Psychology of retirement}

The survey asked a series of questions designed to invoke the feelings, desires and concerns that our respondents have about retirement. As you will see throughout our findings, the decision to retire is much more than a financial decision. Here is what we found to be some of the most intriguing output.

- $\quad$ How do you feel about retirement?

- Our survey found that $56 \%$ of the pre-retirees had mixed emotions about retirement while $68 \%$ of the $3+$ year retirees were excited about retirement.

- The 2011 Retirement Confidence Survey (RCS) found a continued decline in worker confidence in having enough money to live comfortably during their retirement years. Those not at all confident rose to $27 \%$ up from $22 \%$ in 2010 and $10 \%$ in 2007.

- Why did/do you want to retire and what is your primary concern about retirement?

- Over $60 \%$ of all surveyed wanted more schedule flexibility while $52 \%$ reported they wanted to spend more time with their children/grandchildren, followed by $46 \%$ indicating they wanted/want to travel more. Just $30 \%$ of those surveyed today indicated that "Work wasn't/isn't fun anymore" as a reason they wanted/want to retire.

- Our study noted that as one approaches the time for making the decision to retire, almost half $(48 \%)$ were not sure they were ready for retirement and two-thirds $(67 \%)$ of those retired less than three years indicated they had a hard time finding a sense of purpose. This is important information for both the retiree and the financial advisor. Retirement is more than just about money, it's about "living a meaningful life" during retirement. During the retirement planning phase, discussions need to include how the retiree will be spending their "time" as well as spending their "money".

- The survey respondents from the 3+year retirees noted that most (73\%) had no personal concerns. This may indicate that as people become more accustomed to the retirement life they begin to settle into the retirement mode and have found their sense of purpose, a hobby, and/or are comfortable with how they spend their time.

- How did the recent recession affect your plans?

$\circ$ It was interesting to find that $52 \%$ of the pre-retirees reduced their anticipated income in retirement; $80 \%$ of those retired less than 3 years and $42 \%$ of the $3+$ year retirees became more conservative with their assets.

- The 2011 Retirement Confidence Survey (RCS) noted that 36\% of their respondents cited the poor economy for postponing the age at which they expect to retire. More than half of the workers say they expect to retire at age 65 or later. Also, workers are twice as likely to indicate they will retire at age 70 or later.

It seems that many focus a lot of energy on retirement as primarily a financial decision. Realistically, if you are not ready financially, then retiring right now is simply not viable. However, it is important to realize that just because you are financially prepared for retirement, does not mean that you are ready for this change in your lifestyle.

One observation for those who want to retire for schedule flexibility, is to approach your employer to consider scaling back your hours, allowing you to transition psychologically and to pass on your knowledge to the next generation of employee in a manner that is a benefit to all parties involved.

\section{Lifestyle - work and leisure}

SIA's survey included a series of questions to better understand how future retirees intend to incorporate travel, work and volunteerism into their lifestyle and to directly contrast that with how existing retirees are actually incorporating these facets into their lives. The perception versus reality of this created some interesting output, which we believe is useful for those nearing retirement. 
- $\quad$ Do you plan to/do you travel more in retirement?

○ Our survey found that $84 \%$ of pre-retirees plan to travel more while only $61 \%$ of the $3+$ year retirees actually are travelling more. As a follow up to this question, when pre-retirees were asked how much travel you anticipate in retirement each year just $24 \%$ indicated that they thought their travel would be 1 month or less each year, contrast this with $61 \%$ of the 3 +year retirees indicating that they travel 1 month or less each year.

- $\quad$ Do you plan to work in retirement/do you work?

○ It was found that $68 \%$ of the pre-retirees plan to do some type of work while $54 \%$ of the retirees actually do work. The RCS found that $74 \%$ of workers now plan to "work for pay" after they retire, so the local statistic $(68 \%)$ is relatively close to RCS's national survey.

- In the RCS survey, the major reasons for those working for pay were: wanting to stay active in retirement (60\%); enjoying working (59\%); a job opportunity $(26 \%)$; and a decrease in the value of savings or investments $(26 \%)$. While this RCS survey question is different than the questions asked in SIA's survey in the "Psychology of Retirement" section, this national response seems to draw a parallel that many who continue to work do so for non-financial reasons.

- $\quad$ Do you plan to volunteer in retirement?

$\circ$ Our study reported that $88 \%$ of pre-retirees do plan to volunteer while $65 \%$ of the $3+$ year retirees actually do volunteer.

- While most of the pre-retirees $(88 \%)$ believe they will engage in volunteering, it appears that almost a fourth will change their mind and decide not to volunteer. This is an interesting data point and will cause the researchers to inquire about the reasons for this change of heart in future surveys.

The responses of this section demonstrate that while many have a general idea of the activities they will undertake in retirement, the scope of these activities is often overestimated. We suggest those nearing retirement to consider this when preparing for retirement. While we do not know the reasons for the disparity, we are not surprised as we are asking our respondents what their future lifestyle will be like, and in many respects you cannot foresee the specifics of your future daily activities.

\section{Financial aspects of retirement}

The survey included a section dedicated to understanding key financial concerns, and methods for preparing for retirement. Our findings demonstrate areas where professional advisors could focus on providing clarity and guidance. The output also demonstrates areas that pre-retirees may want to understand about how they may think about their own financial situation once in retirement.

- What is your largest financial concern about retirement?

○ Our study reported that $24 \%$ of the pre-retirees cited their largest financial concern in retirement is paying for health and long term care, followed closely by having enough to support lifestyle at $20 \%$ and being forced back to work due to an economic downturn $20 \%$.

- Contrast this with how all retirees responded to this same question. $37 \%$ cited seeing their investment principal drop in value as their largest concern, followed by $20 \%$ worried about having enough to support lifestyle, and $17 \%$ paying for health/long term care.

- It is interesting that supporting lifestyle ranked second in both sets of respondents and that they were both $20 \%$ of the responses. Also what is interesting is that of those retired, not a single respondent answered as being forced back to work due to an economic downturn as a concern when this was a large concern of $20 \%$ of pre-retirees.

- Have you or did you try to calculate how much to save for retirement?

$\circ$ The following responded "yes" to attempting to calculate their retirement needs: $80 \%$ of the preretirees; $55 \%$ of the retirees of less than 3 years and $46 \%$ of those retired $3+$ years. 
- Determining just how much to save for retirement was most important to the pre-retirees which seems very logical. However, the data would indicate that it becomes less important to those already entered into retirement.

- RCS noted that many workers continue to be unaware of how much money they will need at retirement. Less than half of the workers $(42 \%)$ attempted to calculate how much money was needed to live comfortably in retirement.

- The RCS reported that $47 \%$ of those ages $45-54$ and 53\% of ages 55+ tried to calculate how much they will need to save for retirement. In determining the amount of savings needed for retirement, workers ages 55 or more (38\%) were more likely than younger workers (30\%) to believe they will need less than $\$ 250,000$ to live on at retirement age.

- Most workers have little put away in savings and investments for retirement. However, the RCS study found that the propensity to save for retirement increases with age, education, and household income.

- Other interesting results were that more than half of the workers reported having less than $\$ 25,000$ of total saving and investments (excluding their home and benefit plans). Sixty-eight percent reported they have less than $\$ 1,000$ in savings and investments, and 19\% have $\$ 1,000-\$ 9,999$.

- It appeared that many do not have an emergency savings plan noting that $34 \%$ of workers had to dip into savings to pay for basic expenses.

- If you had/have more money than you need, would you give it away during your lifetime?

$\circ$ It was found that $88 \%$ of those surveyed in our study indicated they would give it away during their lifetime and $71 \%$ of those who would give it away during their lifetime would give it to a combination of family and charity. By contrast, only $8 \%$ have made or plan to put provisions in their estate plan for non-family members to receive assets.

- Although most respondents indicate that they would give their assets away either to family or charity, very few are making provisions in their estate plans for non-family to receive assets. Again, this information raises the issue of the importance of professional advisors being instrumental in incorporating "estate-planning" during the retirement planning phase and during actual retirement.

- $\quad$ Do you anticipate having or have debt?

$\circ$ The following results represent having no debt: $60 \%$ of the pre-retirees; $44 \%$ of those retired less than 3 years; and $58 \%$ of the 3 +year retirees.

- Most personal financial advisors (i.e., Dave Ramsey) stress the importance of living a debt-free life especially going into retirement. Although most of those having debt were below $\$ 100,000$, it still is a debt that places a burden on current income. This information provides an opportunity for the financial advisor to stress the importance in becoming "debt free" prior to entering into retirement.

- What are your expectations when working with a financial advisor?

$\circ$ The majority of the respondents want to work with someone within a 30 minute drive from their home and prefer a combination of face-to-face, phone, and email communications.

0 This information is vital for the financial advisor in order to maintain and expand its client base. The clients want to be able to have on-site visits with their advisor and want to be kept informed about their investments. The ongoing development of this client-advisor relationship will be critical for both parties to be successful in the future.

Being prepared financially for retirement is a must for those who want to enjoy their retirement years. Based on the results of this survey being financially prepared is important to those preparing for retirement today. Those pre- and post-retirees seeking professional advice will likely appreciate working with advisors who are local and can help them not only project what they will need for retirement, but do it in a matter that addresses their largest financial concerns. 
In addition, there appear to be many who have considered advanced planning needs such as giving money away during their lifetimes, but few are doing it. Those professionals who can uncover these desires and facilitate action will likely deliver a more fulfilling client experience.

\section{LIMITATIONS OF STUDY}

The survey had no open ended questions which eliminated the gathering of any additional information to be shared by the participants. The sample size of sixty was good, but a higher response rate would have strengthened our statistical power. The main concern of the study was found with the survey design of some of the questions. There was a high frequency of no responses to some of the survey questions. Below is a recap of some of the questions with a high frequency of no responses:

\begin{tabular}{|c|c|c|}
\hline Uestion No. & Question & "No" Responses \\
\hline 5 & $\begin{array}{l}\text { What was your primary reason for the move or second } \\
\text { home? }\end{array}$ & $47(78 \%)$ \\
\hline 16 & $\begin{array}{l}\text { If you work, please pick the answer that best describes } \\
\text { that job. }\end{array}$ & $27(45 \%)$ \\
\hline 17 & $\begin{array}{l}\text { Select the range of hours that best describes your work in } \\
\text { retirement. }\end{array}$ & $26(43 \%)$ \\
\hline 19 & $\begin{array}{l}\text { Select the range of hours that best describes your volunteer- } \\
\text { ing in retirement. }\end{array}$ & $19(32 \%)$ \\
\hline 25 & $\begin{array}{l}\text { What was (were) your method(s) for determining the amount } \\
\text { of savings needed (select all that apply). }\end{array}$ & $24(40 \%)$ \\
\hline 26 & $\begin{array}{l}\text { How would you describe the effect the recession had on your } \\
\text { retirement (check all that apply). }\end{array}$ & $19(32 \%)$ \\
\hline 27 & $\begin{array}{l}\text { Rank what is more important to you about your assets. (rank } \\
\text { them 1-6, with } 1 \text { being the highest concern). }\end{array}$ & $28(46 \%)$ \\
\hline 32 & $\begin{array}{l}\text { Indicate the percentage of your assets that you anticipate } \\
\text { going to: family members; individuals not family members; } \\
\text { my church; educational institutions; other charities. }\end{array}$ & $56(93 \%)$ \\
\hline 42 & $\begin{array}{l}\text { How much debt (including mortgage): less than } \$ 100,000 \text {; } \\
\text { between } \$ 100,000 \text { and } \$ 250,000 ; \text { over } \$ 250,000 ; \text { I don't know. }\end{array}$ & $36(60 \%)$ \\
\hline 43 & $\begin{array}{l}\text { Explain your monthly payments for debt: less than } \$ 1,000 \text {; } \\
\text { between } \$ 1,000 \text { and } \$ 2,000 ; \text { over } \$ 2,000 ; \text { I don't know. }\end{array}$ & $35(58 \%)$ \\
\hline
\end{tabular}

The researchers will examine these questions to determine plausible causes for the no responses and will contact some of the clientele for their input. Looking at Q\# 32 above, it may be difficult to determine a percentage as a dollar amount allocated to a charity. Also, ranking the importance of assets (see Q\#27) may be too difficult to prioritize. Obviously, changes to these questions must be addressed before moving forward with the research. The respondents were particularly sensitive or uncertain to questions pertaining to reasons for moving; percentage of assets being allocated at death; and the amount of debt.

\section{IMPLICATIONS FOR FURTHER RESEARCH}

Before moving forward with the next phase of this study, more research is needed to determine the reasons for the lack of responses to the questions noted above. The researchers will need to consider the best way to obtain this information. Several methods to consider would be to conduct telephone interviews or face-to-face interviews with several of the respondents. The original questionnaire will need to be revised based on the outcome of the client interviews. After the revised questionnaire is complete, it will be piloted to a small test group for their evaluation and critique. 


\section{CONCLUSION}

Our results agreed with earlier research that workers have less confidence in having enough money to live comfortably during their retirement years which may be the cause for more workers staying in the workforce longer (Carrns, 2010; Malonebearch \& Langeland, 2011).

It was found that more than half of the workers reported having less than $\$ 25,000$ in total investments while about $70 \%$ have less than $\$ 1,000$ in savings and investments. This supports earlier findings that baby boomers are not saving enough for retirement (Rosnick \& Baker, 2010; Wolff, 2002; Weller \& Wolff, 2005). Less than 50\% of the participants attempted to calculate how much it would cost to live comfortably in retirement. About $40 \%$ of the retirees were concerned about their investment values declining while less than a quarter of the pre-retirees were concerned about paying for health care during retirement.

Some of the retirees in the study reported having debt which most noted was less than $\$ 100,000$. This debt does place some restrictions on current income and could have a negative impact on lifestyle. Not having enough retirement income may impact the lifestyle choices for the baby boomers. Over 50\% of the retirees in our study worked during retirement and over a quarter cited the reason for working was due to the decrease in their investments from the economic downturn. Our study found that $60 \%$ of the retirees travelled less than one month per year. Only a few of the study's retirees made provisions in their estate plans for "non-family" members to receive assets.

Our findings support the need and importance of professional financial advisors in helping those who are planning for retirement. We recommend to financial advisors to focus on the following areas in assisting future retirees: planning for retirement through regular savings, determining the cost of retirement living, estate-planning, and providing estimates for health care costs.

\section{AUTHOR INFORMATION}

Chris Ward, Ed.D., is an Associate Professor of Business with The University of Findlay. Contact information: The University of Findlay, 1000 North Main Street, Findlay, Ohio 45840 USA. E-mail: cward@ findlay.edu

Professor Ward brings her expertise from two Fortune 500 companies into the classroom teaching operations and logistics, marketing, and research. Professor Ward holds the following degrees: University of Sarasota, EdD, Organizational Leadership; The University of Findlay, MBA and The University of Findlay, Bachelor of Science in Business Administration. She is also a Six Sigma Black Belt, a 2008 Ohio Partnership for Excellence Examiner, and completed the NxLevel Certification Course for Instructor Certification for teaching business plans. Her areas of research include student engagement, active learning, and assessment.

Dan Yates, Ph.D., is an Associate Professor of business at The University of Findlay. Contact information: The University of Findlay, 1000 North Main Street, Findlay, Ohio 45840 USA. E-mail: yates@findlay.edu (Corresponding author)

His teaching interests include personal finance, entrepreneurship, leadership, organization development, and business strategy. Yates holds a PhD degree in Management from Northcentral University. He also has a MBA from University of Dayton, a Master of Organization Development degree from Bowling Green State University, and a BS in Accounting from Tiffin University. He completed the NxLevel Certification Course for Instructor Certification for teaching business plans at the Innovation Center (Ohio University). He has 30 years industrial and governmental experience.

\section{REFERENCES}

1. Baker, D., \& Rosnick, D. (2008). The housing crash and the retirement prospects of late baby boomers. Washington, DC: Center for Economic and Policy Research.

2. Carrns, A. (2010, October). Taking Stock (and Coming Up Short). U.S. News \& World Report, pp. 22-28. 
3. Helman, R., Copeland, C., \& VanDerhei, J. (2011). The 2011 Retirement Confidence Survey: Confidence Drops to Record Lows, Reflecting "the New Normal". EBRI Issue Brief, no. 355, Employee Benefit Research Institute.

4. Krepcio, K. (2007). Baby Boomers in Retirement: Implications for the Workforce. Journal of Jewish Communal Service, Summer, Vol. 82, No.3, 155-158.

5. Malonebeach, E., \& Langeland, K. (2011). Boomers' Prospective Needs for Senior Centers and Related Services: A Survey of Persons 50-59. Journal of Gerontological Social Works, 54:116-130.

6. Mess, A. M. (2010). Estate Planning for the Baby Boomers. GPSolo, Vol.27 Issue2, 42-43.

7. Munnell, A. H., Golub-Sass, F., \& Webb, A. (2008). Do households have a good sense of their retirement preparedness? Issue in Brief, 8-11. Chestnut Hill, MA: Center for Retirement Research at Boston College.

8. Rosnic, D., \& Baker, D. (2010). The Impact of the Housing Crash on the Wealth of the Baby Boom Cohorts. Journal of Aging \& Social Policy, 22: 117-128.

9. Rosnick, D., \& Baker, D. (2009). The wealth of the baby boom cohorts after the collapse of the housing bubble. Washington, DC: Center for Economic and Policy Research.

10. Stephen, G. (2009, May 25). Why Boomers Can't Quit. Time, p. 46.

11. Weller, C., \& Wolff, E. N. (2005). Retirement income: The crucial role of social security. Washington, D.C.: Economic Policy Institute.

12. Wolff, E. N. (2002). Retirement insecurity: The income shortfalls awaiting the soon-to-retire. Washington, D.C.: Economic Policy Institute.

13. You'll Work Longer. (2011, February). Kiplinger's Personal Finance, p. 56. 


\section{NOTES}

